\title{
Phytoplankton balance in the oceanic subarctic Pacific: grazing impact of Metridia pacifica
}

\author{
Harold P. Batchelder* \\ College of Oceanography, Oregon State University, Corvallis, Oregon 97331, USA
}

\begin{abstract}
Ingestion and respiration by Metridia pacifica, the dominant large copepod during autumn and winter in the subarctic Pacific, were investigated by shipboard and laboratory experiments. Diel variation in the rate of grazing on phytoplankton by $M$. pacifica was determined from measurements of gut pigment content and gastric evacuation rate. Both adult females and $\mathrm{C}_{5}$ copepodites exhibited marked diel variation in gut contents, and thus feeding intensity. Night gut pigment values were 10 times greater than daytime values. Ingestion rates during May 1984 were 51.7

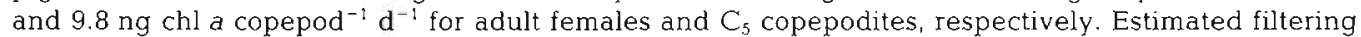
rates were $76 \mathrm{ml}$ female $\mathrm{d}^{-1}$ and $15 \mathrm{ml} \mathrm{C}_{5}^{-1} \mathrm{~d}^{-1}$. Feeding rates at low food concentrations in incubation bottles were similar to estimates obtained from in situ studies. Adult females consumed approximately $7.5 \%$ of body carbon $\mathrm{d}^{-1}$, and $\mathrm{C}_{5}$ copepodites only $2.5 \% \mathrm{~d}^{-1}$. Respiration was 4 to $10 \%$ of body carbon $\mathrm{d}^{-1}$ for both $\mathrm{C}_{5}$ and adults, indicating approximate energy balance for females but higher daily energy expenditure than gain for $C_{5}$. Based on the respiration measurements, a model was developed to evaluate the seasonal grazing impact of $M$. pacifica on the phytoplankton standing crop in the subarctic Pacific. During peak phytoplankton production in summer, the low densities of $M$. pacifica require less than $10 \%$ of daily primary production to satisfy metabolic, growth and reproduction requirements. In contrast, during autumn and winter, the $M$. pacifica population requires 36 to $57 \%$ and exceptionally $175 \%$ of daily primary production to satisfy its energy requirements. $M$. pacifica contributes significantly to the total qrazing potential responsible for maintaining low stocks of phytoplankton during the unproductive, fall-winter season in the eastern subarctic Pacific.
\end{abstract}

\section{INTRODUCTION}

The oceanic region of the subarctic Pacific has a close temporal and spatial coupling between primary production and herbivore consumption (Heinrich 1962). As a result, the summer increase in primary production does not increase phytoplankton stocks; it increases zooplankton stocks, and the strong seasonal peak of plant biomass, typical of most temperate and boreal ocean regions, does not occur in the subarctic Pacific.

A previous numerical model of the phytoplankton and zooplankton dynamics of the subarctic Pacific (Parslow 1981) represented Neocalanus plumchrus and $N$. cristatus as the herbivores primarily responsible for cropping plant production. This principal role of Neocalanus was suggested by Heinrich $(1957,1962)$ because the overwintering strategy and reproduction

- Present address: Graduate School of Oceanography, University of Rhode Island, Narragansett, Rhode Island 02882, USA of these 2 copepods prior to the spring bloom appeared appropriate for immediate grazing control of the spring phytoplankton bloom. Miller et al. (1984) documented the life cycles of the 2 Neocalanus spp. at Station P, and concluded that the timing of their life cycles was suitable for grazing control of the spring bloom in the subarctic Pacific. However, models which relied solely upon Neocalanus grazing for control of phytoplankton stocks became unbalanced during the autumn after the Neocalanus spp. descended to depth and entered diapause. Parslow (1981) concluded that grazing control after the departure of the large grazers from the euphotic zone must be provided by smaller herbivores, but it was difficult to simulate a smooth transition of grazing pressure from the larger Neocalanus to smaller unspecified grazers. The copepod Metridia pacifica (2.4 to $3.3 \mathrm{~mm}$ total length), may be an important grazer during autumn in the subarctic Pacific, since its population size increases soon after the Neocalanus spp. depart from the euphotic zone in July (Batchelder 1985). Except for the very small copepods, such as 
Oithona spp., Metridia copepodites and adults were the most abundant metazoan herbivores in the surface mixed layer during autumn and winter 1980-1981 (Miller et al. 1984, Batchelder 1985).

In this study a carbon budget for Stage $C_{5}$ and female Metridia pacifica is presented based upon experimental determination of ingestion and respiration rates. These results are used to model the potential of these smaller herbivores to maintain constant, low phytoplankton stocks in the subarctic Pacific.

\section{METHODS}

Collection of copepods. Metridia pacifica for experimental studies were collected during summer 1982 and 1983 from coastal Oregon waters $\left(44^{\circ} 40^{\prime} \mathrm{N}\right)$, in summer 1984 from Station P $\left(50^{\circ} \mathrm{N}, 145^{\circ} \mathrm{W}\right)$, and in fall 1984 from Dabob Bay, Washington $\left(47^{\circ} 45^{\prime} \mathrm{N}\right.$, $122^{\circ} 49^{\prime} \mathrm{W}$ ). Zooplankton were sampled using a $0.70 \mathrm{~m}$ diameter net of $243 \mu \mathrm{m}$ mesh equipped with a large volume, slow-filtering cod-end. Vertical or oblique hauls from 50,70 or $100 \mathrm{~m}$ to the surface provided specimens for grazing and respiration incubations. Copepods were either gently poured into a $19 \mathrm{I}$ plastic pail, from which they were sorted, or sorted directly from the cod-end into 0.5 to 1.01 containers of surface seawater screened at 64 or $200 \mu \mathrm{m}$, or Whatman GF/C filtered. Sorting began immediately after collection and was completed within 2 to $3 \mathrm{~h}$.

Diel variation of phytoplankton pigments in gut contents. In situ ingestion rate was estimated by measurement of the amount and turnover rate of phytoplankton pigment in the guts of freshly collected copepods. Zooplankton samples collected from the upper 50 to 100 mat Station Pevery 3 hovera 27 h period on 16 and 17 May 1984 were used to evaluate phytoplankton pigments in the guts of Metridia pacifica. After each collection, up to 5 replicates of 8 to 16 individuals of both adult females and $\mathrm{C}_{5}$ copepodites were sorted into small tubes and kept in the dark. The samples were not frozen prior to sorting; however sorting was completed within 10 to $15 \mathrm{~min}$ from the time of collection and at the measured gut evacuation rates this time interval would not affect the in situ pigment values much. The method of Mackas \& Bohrer (1976), as modified by Dagg \& Grill (1980), was used to measure copepod gut fluorescence. For each analysis, the copepods were homogenized in 4 to $6 \mathrm{ml}$ of $90 \%$ acetone, filtered through a Whatman GF' $C$ glass fiber filter, and the fluorescence of the filtrate measured with a Turner Designs Model 10 fluorometer, before and after acidification. The pigment content per copepod was calculated according to the equations: ng chlorophyll ind in $^{-1}=\frac{V}{N}\left(F_{0}-F_{a}\right) C$

ng phaeopigment ind ${ }^{-1}=\frac{V}{N}\left(T_{a}-F_{o}\right) C$

where $F_{0}$ and $F_{a}=$ fluorescence readings before and after acidification, respectively; $N=$ number of copepods; $T=$ maximum acidification ratio; $\mathrm{V}=\mathrm{vol}$ ume of acetone used to extract the pigments; and $\mathrm{C}=$ a machine-dependent calibration factor. The phaeopigment content of the gut was multiplied by 1.51 as suggested by Shuman \& Lorenzen (1975) to correct for the molar conversion of chlorophyll a to phaeophorbide to yield the chlorophyll a equivalent. Conover et al. (1986) have recently shown that Shuman \& Lorenzen (1975) were incorrect in using 1.51 to correct for the molar conversion of chlorophyll a to phaeophorbide. In fact, the fluorescence values are already expressed on a molar basis and no correction is necessary. Conover et al. (1986) suggest that the apparent need for a correction arose from destruction (nonconservativeness) of plant pigments during gut passage. It was an unfortunate coincidence that the amount of destruction of pigment in the gut of Calanus pacificus $(34 \%)$ was the amount corrected by the molar equivalent weight difference of chlorophyll a and phaeophorbide. In the current study, destruction of pigment during passage through the gut was not measured. Nevertheless, while it may not be correct to assume that $34 \%$ of the pigments were destroyed during passage through $M$. pacifica, as was found for C. pacificus, this assumption was made to allow comparison of the ingestion results reported here with ingestion rates found for other species using this method.

Experiments to determine the gut evacuation rate of Metridia pacifica, and thus estimate ingestion from observed in situ gut contents, were done both at sea and ashore. Copepods, previously fed on unialgal cultures of either Thalassiosira weissflogii (10 to $15 \mu \mathrm{m}$ diameter) or Corethron hystrix (ca $25 \mu \mathrm{m}$ by $70 \mu \mathrm{m}$ ), were transferred to filtered seawater. Groups of 4 to 10 specimens were removed intermittently over the following 1 to $3 \mathrm{~h}$ and analyzed for gut pigment content. Initial gut fullness of $M$. pacifica used in these experiments varied from low values similar to those found in the field, to values (ca $20 \mathrm{ng} \mathrm{chl} a$ ind $^{-1}$ ) much higher than observed in the field.

Incubation grazing experiments. Metridia pacifica females collected from off the Oregon coast (Summer 1983), from Dabob Bay, Washington (September 1984), and from Station P (May, August 1984) were used to investigate grazing capabilities. The functional response curve of $M$. pacifica females feeding on Thalassiosira weissflogii was determined from $24 \mathrm{~h}$ 
incubations. Initial and final cell concentrations for experiments during summer 1983 were determined using a model ZBi Coulter Counter equipped with a $70 \mu \mathrm{m}$ aperture tube. A Particle Data electronic counter, fitted with either a 95 or $190 \mu \mathrm{m}$ aperture tube, was used to determine cell densities during 1984. In addition, Corethron hystrix was used as food in one experiment to investigate the effect of particle size on ingestion. Cell counts and cell volumes for this experiment were determined microscopically.

For each functional response experiment, 2 replicate containers with 10 to 15 copepods, and one control without copepods, were prepared for each of 4 to 5 food levels. Specimens were incubated in $700 \mathrm{ml}$ glass beakers or $500 \mathrm{ml}$ polycarbonate bottles containing $500 \mathrm{ml}$ of the food medium. The differential effect of ammonia excretion by the copepods on phytoplankton growth was minimized by adding 5 to $10 \mu \mathrm{mol} \mathrm{NH} \mathrm{N}_{4} \mathrm{Cl}$ $\mathrm{l}^{-1}$ to each container at the beginning of each experiment. Incubations lasted 20 to $30 \mathrm{~h}$, and were conducted in a constant temperature cold room. All containers were gently stirred several times hourly by a plunger-stirrer, which maintained the phytoplankton in suspension. Incubations during 1983 were conducted at 10 to $12.5^{\circ} \mathrm{C}$ under constant cool-light illumination $\left(60\right.$ to $\left.80 \mu \mathrm{E} \mathrm{m} \mathrm{m}^{-2} \mathrm{~s}^{-1}\right)$. The September 1984 experiments were performed in constant darkness at 8 , 12 , and $15^{\circ} \mathrm{C}$. Shipboard experiments were conducted in on-deck incubators at sea surface temperature with the natural daylight cycle. Ingestion and filtration rates worc calculatcd by the equations of Frost (1972). Ingested particle volume was converted to carbon using the equation of Mullin et al. (1966). All food levels and ingestion rates are presented on a carbon basis to facilitate comparison among experiments.

Respiration experiments. Respiratory rate of Metridia pacifica was measured in bottle incubations during May and August 1984 at Station P. Copepods were collected by net hauls as described above. Fifteen to 30 $\mathrm{C}_{5}$ copepodites or adult females were sorted into $300 \mathrm{ml}$ BOD bottles filled with 64 or 200 um screened surface seawater. Control bottles, filled with identical water but lacking copepods, were run concurrently. The bottles were placed in deck incubators for 12 to $24 \mathrm{~h}$. Oxygen consumption by adult females was measured at 8,9 and $14.6^{\circ} \mathrm{C}$, but only at 8 to $9^{\circ} \mathrm{C}$ for $\mathrm{C}_{5}$ copepodites. The oxygen concentration in initial, final experimental and final control bottles was measured by Winkler titration. The measured respiration rates in $\mu \mathrm{l} \mathrm{O}_{2}$ ind $\mathrm{d}^{-1} \mathrm{~h}^{-1}$ were converted to $\mu \mathrm{g}$ carbon ind $\mathrm{d}^{-1} \mathrm{~h}^{-1}$ using a respiratory quotient of 0.9 (Parsons et al. 1984).

Seasonal length variation and length-weight relations. Seasonal variation of body size of Metridia pacifica was described from samples collected at Station P from February 1980 to March 1981 (for collection methods see Miller et al. 1984). Total length, excluding caudal setae, of $\mathrm{N}_{4}, \mathrm{~N}_{5}, \mathrm{C}_{3}, \mathrm{C}_{4}, \mathrm{C}_{5}$ males and females, and adult females was measured using a calibrated ocular micrometer. Usually 25 to 50 individuals of each life stage were measured from each 0 to $100 \mathrm{~m}$ sample. On dates when the depth of the mixed layer was shallower than $100 \mathrm{~m}, 25$ to 50 individuals of each stage were measured from both the $100 \mathrm{~m}$ to thermocline sample and the thermocline to $0 \mathrm{~m}$ sample. An abundance-weighted size distribution was then calculated for the $100 \mathrm{~m}$ layer.

A length-weight relation for Metridia pacifica was determined from freshly collected individuals of the older life stages $\left(\mathrm{C}_{4}\right.$ to adult) and from formalin-preserved $C_{1}$ to $C_{3}$ copepodites. Specimens were measured for total length, rinsed briefly in distilled water, transferred to precombusted Whatman QM/A quartz fiber filters, and dried at $60^{\circ} \mathrm{C}$. Carbon contents for both live-sorted and formalin-preserved samples were analyzed ashore using a Perkin Elmer Model 240C Elemental Analyzer.

\section{RESULTS}

\section{Diel variation of gut content fluorescence}

The variation of chlorophyll a equivalent per $\mathrm{C}_{5}$ and female Metridia pacifica during a $27 \mathrm{~h}$ period in May 1984 is shown in Fig. 1. During daytime, adult females contained little pignient, ranging from 0.4 to $0.6 \mathrm{ng}$ chl a female ${ }^{-1}$; whereas females collected at $2200 \mathrm{~h}$ and $0100 \mathrm{~h}$ averaged 5.7 and $5.9 \mathrm{ng}$ chl a female ${ }^{-1}$, respectively. The diel cycle of gut pigment of $C_{5}$ copepodites was similar, but of lower amplitude (Fig. 1). Daytime values were always less than $0.24 \mathrm{ng}$ chl a $\mathrm{C}_{5}^{-1}$, compared to 0.8 to $1.2 \mathrm{ng} \mathrm{chl} \mathrm{a} \mathrm{C}_{5}^{-1}$ at night.

Metridia pacifica are dramatic diel vertical migrators (Batchelder 1985), and this alone should result in a diel cycle of gut contents as the copepods descend to depths during the day where chlorophyll values are very low. However, not all individuals left the surface during the day, and to evaluate diel ingestion without the complications of vertical migration, only individuals from the upper mixed layer were analyzed for gut pigment content. Since the percent change in ambient water chlorophyll (Fig. 1) of the upper mixed layer was much less than was observed for gut chlorophyll, the temporal change of chlorophyll equivalent per copepod implies a real difference in feeding intensity between day and night, not an effect of vertical migration or change in food availability. The time course of pigment loss from the guts of adult females after transfer to filtered seawater is shown in Fig. 2 for 5 experi- 

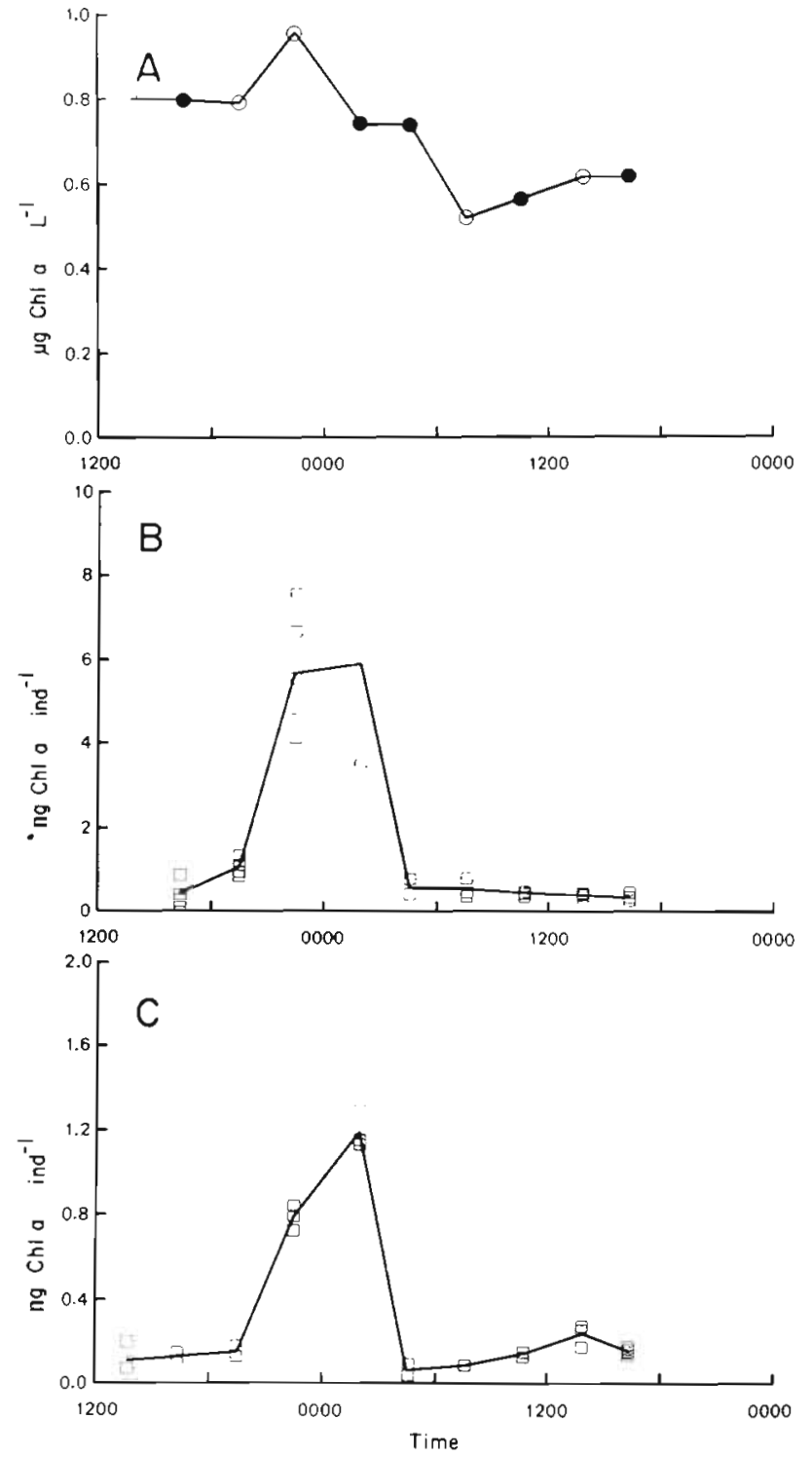

Fig. 1. Metridia pacifica. Diel variation of water chlorophyll a and pigment content at Station P during 16-17 May 1984. (A) Water chlorophyll (O: measured; $\bullet$ : interpolated): (B) adult female; (C) $\mathrm{C}_{S}$ copepodite

ments. Pigment content declined rapidly over the first hour. The gut evacuation rate was described by the exponential relation:

$$
\mathrm{S}_{\mathrm{t}}=\mathrm{S}_{\mathrm{o}} \mathrm{e}^{-\mathrm{Et}}
$$

where $\mathrm{S}_{0}=$ amount of pigment in the gut at time zero; $\mathrm{S}_{\mathrm{t}}=$ pigment content at time $\mathrm{t}_{\mathrm{i}}$ and $\mathrm{E}=$ instantaneous gut evacuation rate $\left(\mathrm{min}^{-1}\right)$ (Dagg \& Wyman 1983). Gut evacuation rate ranged from 1.4 to $2.4 \% \mathrm{~min}^{-1}$ (Table 1), with no consistent relation to temperature, food type or initial gut fullness. Pooling and scaling the data from all 5 experiments yields an overall mean evacuation rate of $1.8 \% \mathrm{~min}^{-1}$.
Gut evacuation rate of adult females was independently estimated from the decline in mean gut pigment from 0158 to $0436 \mathrm{~h}$ on 17 May 1984, assuming the decline during that interval resulted from cessation of feeding activity. If the copepods stopped feeding at $0158 \mathrm{~h}$, the gut evacuation rate necessary to decrease the gut contents to $0.54 \mathrm{ng}$ pigment ind $\mathrm{d}^{-1}$ at $0436 \mathrm{~h}$ is calculated from Equation (3) to be $1.53 \% \mathrm{~min}^{-1}$, in good agreement with the laboratory results.

In situ ingestion rate was determined from the diel cycle of gut pigment (Fig. 1) using an instantaneous gut evacuation rate of $1.8 \% \mathrm{~min}^{-1}$ (Table 2). Total consumption $\left(C_{t}\right)$ for each time interval $(t)$ was calculated from:

$$
C_{t}=\frac{\left(S_{t}-S_{o} e^{-E t}\right) E t}{1-e^{-E t}}
$$

(Elliot \& Persson 1978) where $S_{0}$ and $S_{t}=$ amount of pigment in the gut at the beginning and end of the time interval, respectively; and $E=$ instantaneous gut evacuation rate. This relation assumes that the evacuation rate is exponential and that consumption rate during the interval remains constant. Ingestion rates of both females and $\mathrm{C}_{5}$ appear to have been greatest near midnight (Table 2). Total daily consumption was 9.8 and $51.7 \mathrm{ng}$ chl $a$ for $\mathrm{C}_{5}$ and adult females, respectively. Since the specific depth at which the copepods were feeding was not known from vertical collections, the highest chlorophyll a concentration of the mixed layer was used to provide conservative estimates of filtration rate for each sampling time (Table 2). Daily volume swept clear was $76 \mathrm{ml}$ ind $^{-1}$ for adult females and $15 \mathrm{ml}$ ind $^{-1}$ for $\mathrm{C}_{5}$.

\section{Grazing incubations}

Table 3 summarizes the experimental conditions and phytoplankton used in the feeding experiments. Functional response curves in most experiments appeared curvilinear and were described by the Ivlev (1955) equation as modified by Parsons et al. (1967):

$$
I=I_{\max }\left(1-e^{a\left(P_{0}-P_{)}\right.}\right)
$$

where $I_{\max }=$ maximum ingestion rate $; \mathrm{a}=\mathrm{a}$ constant related to the initial slope of the curve; and $P_{0}=$ threshold food level below which ingestion ceases. In none of the experiments was $P_{0}$ significantly different from zero. Ingestion rates of Metridia pacifica females feeding on Thalassiosira weissfloggii were higher in the dark than in the light (Fig. 3A,B).

Metridia pacifica adult females exhibited a hunger response (Runge 1980). Females preconditioned for $36 \mathrm{~h}$ at $450 \mu \mathrm{g}$ carbon $\mathrm{l}^{-1}$ of Thalassiosira weissfloggii had lower ingestion rates than females which were not 
Fig. 2. Metridia pacifica. Time course of gut pigment evacuation for adult females. Symbols as in Table 1

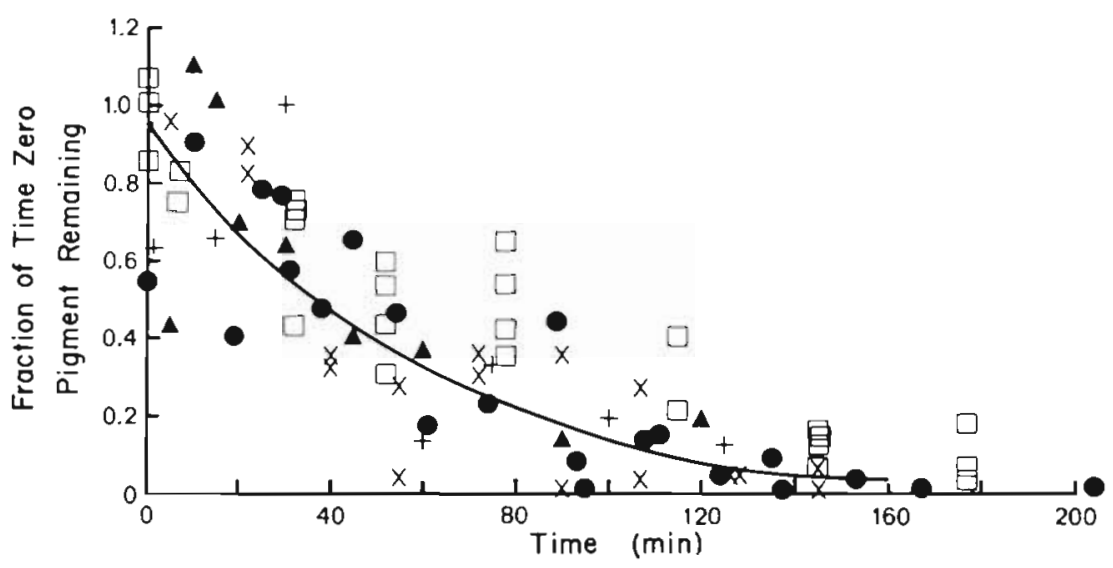

Table 1. Metridia pacifica. Results of adult female gut evacuation experiments. Tw: Thalassiosira weissflogii; Ch: Corethron hystrix.

\begin{tabular}{|cccccc|}
\hline Date & Temp. $\left({ }^{\circ} \mathrm{C}\right)$ & Food & Evacuation $\left(\mathrm{min}^{-1}\right)$ & $\mathrm{R}^{2}$ & Symbol in Fig. 2 \\
\hline 16 Jun 83 & 10.2 & Tw & 0.016 & 0.538 & + \\
22 Jun 83 & 10.2 & Tw & 0.024 & 0.616 & $\times$ \\
23 Jul 83 & 13.5 & Ch & 0.014 & 0.861 & $\square$ \\
19 May 84 & 8.4 & Tw & 0.022 & 0.766 & $\bullet$ \\
16 Nov 84 & 12.0 & Tw & 0.017 & 0.762 & \\
\hline
\end{tabular}

Table 2. Metridia pacifica. Diel dycle of ingestion and filtration rate of $\mathrm{C}_{5}$ and females at Station P during May 1984 . Values in pareniheses are tìe number oí repincates

\begin{tabular}{|c|c|c|c|c|c|c|c|c|}
\hline \multirow[t]{2}{*}{ Date } & \multirow[t]{2}{*}{ Time $(\mathrm{h})$} & \multirow{2}{*}{$\begin{array}{l}\text { Water chla } \\
\left(\mathrm{ng} \mathrm{ml^{-1 }}\right)\end{array}$} & \multicolumn{3}{|c|}{ Adult female } & \multicolumn{3}{|c|}{$\mathrm{C}_{5}$ copepodite } \\
\hline & & & $\begin{array}{c}\text { Ingestion } \\
\text { (ng ind } \text { ind }^{-1} \text { ) }\end{array}$ & & $\begin{array}{l}\text { Filtration } \\
\left(\mathrm{ml} \text { ind }^{-1} \mathrm{~h}^{-1}\right)\end{array}$ & $\begin{array}{c}\text { Ingestion } \\
\left(\text { ng ind }{ }^{-1} \mathrm{~h}^{-1}\right)\end{array}$ & & $\begin{array}{l}\text { Filtration } \\
\left(m l \text { ind } d^{-1} h^{-1}\right)\end{array}$ \\
\hline \multirow[t]{4}{*}{16 May } & 1345 & 0.80 & - & & - & $0.10-0.27$ & (3) & $0.13-0.34$ \\
\hline & 1622 & $0.80^{\circ}$ & $0.19-1.12$ & (5) & $0.24-1.40$ & $0.16-0.21$ & (2) & $0.20-0.27$ \\
\hline & 1930 & 0.79 & $1.12-1.80$ & (4) & $1.42-2.28$ & $0.18-0.26$ & (3) & $0.23-0.33$ \\
\hline & 2228 & 0.96 & $5.54-10.16$ & (5) & $5.77-10.58$ & $0.99-1.70$ & (3) & $1.03-1.32$ \\
\hline \multirow[t]{6}{*}{17 May } & 0158 & $0.74^{\bullet}$ & $4.66-10.23$ & (3) & $6.30-13.82$ & $1.54-1.75$ & (3) & $2.08-2.37$ \\
\hline & 0436 & $0.74^{\bullet}$ & $0.53-1.06$ & (3) & $0.72-1.43$ & $0.07-0.14$ & (3) & $0.09-0.19$ \\
\hline & 0737 & 0.52 & $0.52-1.08$ & (4) & $1.00-2.08$ & 0.13 & (1) & 0.25 \\
\hline & 1045 & $0.57^{\bullet}$ & $0.49-0.66$ & (3) & $0.86-1.16$ & $0.19-0.22$ & (3) & $0.33-0.39$ \\
\hline & 1352 & 0.62 & $0.45-0.59$ & (3) & $0.73-0.95$ & $0.25-0.38$ & (3) & $0.41-0.62$ \\
\hline & 1620 & $0.62^{\circ}$ & $0.34-0.61$ & (3) & $0.55-0.98$ & $0.19-0.24$ & (3) & $0.30-0.39$ \\
\hline
\end{tabular}

preconditioned or were preconditioned in filtered seawater for 6 to $18 \mathrm{~h}$ (Fig. 3A). $\mathrm{I}_{\max }$ for specimens preconditioned on high food was $1.92 \mu \mathrm{g} \mathrm{C}$ ind $\mathrm{d}^{-1} \mathrm{~d}^{-1}$, compared to $4.75 \mu \mathrm{g} \mathrm{C}$ ind $\mathrm{d}^{-1} \mathrm{~d}^{-1}$ for specimens starved prior to the experiment.

Ingestion rates of Metridia pacifica feeding on Thalassiosira weissfloggii in the dark were tempera- ture dependent (Fig. 3B). At the 2 lowest food concentrations, 25 and $75 \mu \mathrm{g} \mathrm{C} 1^{-1}$, ingestion rates were similar at 8.0 and $12.0^{\circ} \mathrm{C}$. However at 250 and $570 \mu \mathrm{g} \mathrm{Cl} 1^{-1}$. ingestion was higher at $12^{\circ} \mathrm{C}$ than at $8^{\circ} \mathrm{C}$. $I_{\max }$ was $4.9 \mu \mathrm{g} \mathrm{C}$ ind ${ }^{-1} \mathrm{~d}^{-1}$ at $8^{\circ} \mathrm{C}$ and $8.2 \mu \mathrm{g} \mathrm{C}$ ind ${ }^{-1} \mathrm{~d}^{-1}$ at $12^{\circ} \mathrm{C}$. Ingestion at $15^{\circ} \mathrm{C}$ was linearly, rather than curvilinearly, related to food abundance. Apparently 
Table 3. Metridia pacifica. Experimental conditions, collection site, and dates of ingestion rate incubations. Tw: Thalassiosira weissflogii; Ch: Corethron hystrix; FSW: filtered seawater

\begin{tabular}{|c|c|c|c|c|c|c|}
\hline Date & $\begin{array}{l}\text { Collection } \\
\text { site }\end{array}$ & Temp. $\left({ }^{\circ} \mathrm{C}\right)$ & $\begin{array}{c}\text { Light } \\
\left(\mu \mathrm{E} \mathrm{m}^{-2} s^{-1}\right)\end{array}$ & Precondition & Food type & $\begin{array}{l}\text { Symbol in } \\
\text { Fig. 3A }\end{array}$ \\
\hline 19 Sep 81 & Oregon & 8.0 & $5-20$ & None & Tw & $\bullet$ \\
\hline 18 May 83 & Oregon & 12.5 & $60-80$ & $36 \mathrm{~h}$ at $450 \mu \mathrm{gC} \mathrm{l}^{-1}$ & Tw & + \\
\hline 14 Jun 83 & Oregon & 10.0 & $60-80$ & $12 \mathrm{~h}$ in FSW & Tw & $x$ \\
\hline 21 Jun 83 & Oregon & 10.2 & $60-80$ & $6 \mathrm{~h}$ in FSW & Tw & $\square$ \\
\hline 22 Jul 83 & Oregon & 13.5 & Low light & $18 \mathrm{~h}$ in FSW & $\mathrm{Ch}$ & \\
\hline 11 Sep 84 & Dabob Bay & $8,12,15$ & Dark & None & Tw & \\
\hline
\end{tabular}
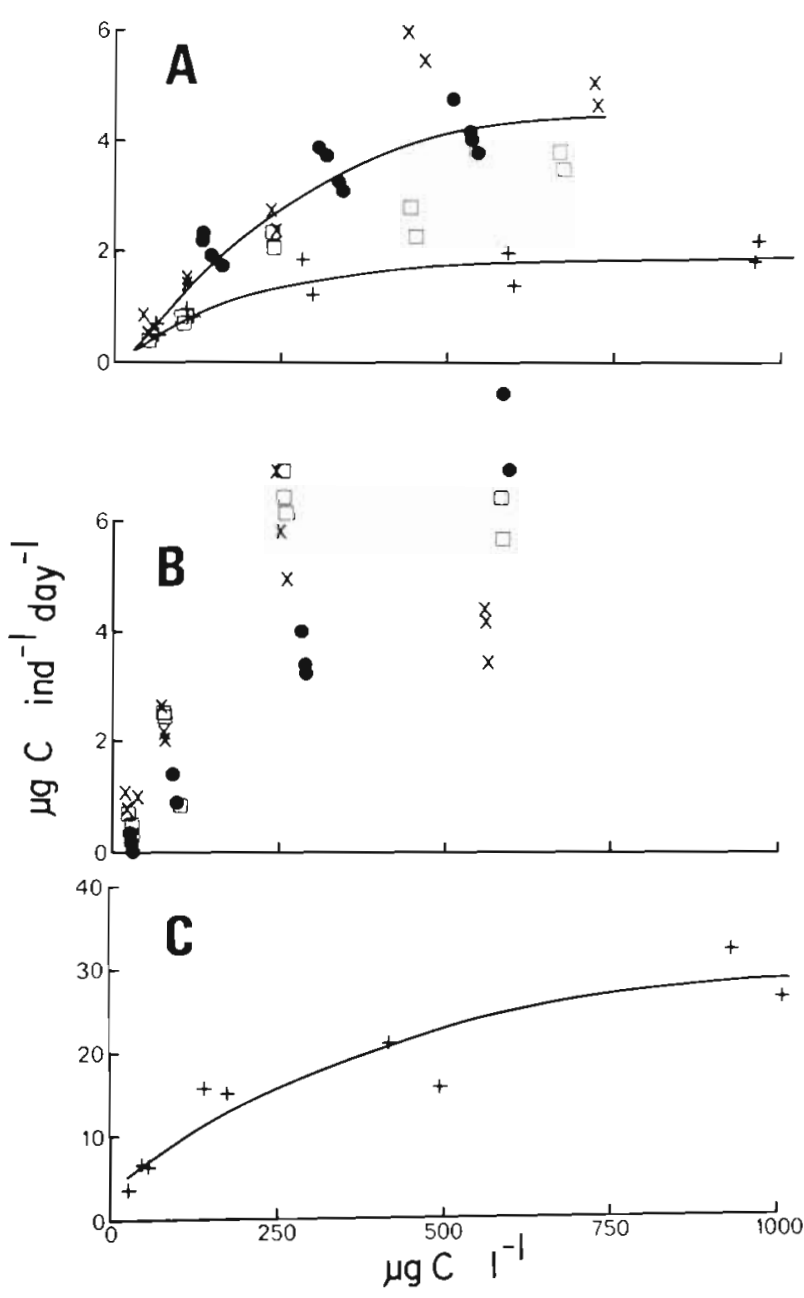

Fig. 3. Metridia pacifica. Ingestion rates of adult females. Curves in (A) and (C) are best Ivlev fit to the data. (A) Feeding on Thalassiosira weissfloggii in the light (lower curve: high food preconditioned; upper curve: low food preconditioned); (B) feeding on $T$. weissfloggii in the dark $\left(\times: 8^{\circ} \mathrm{C}_{;} \square: 12^{\circ} \mathrm{C}_{i} \bullet\right.$ $15^{\circ} \mathrm{C}$ ); (C) feeding on Corethron hystrix (note scale change from (A) and (B))

food levels exceeding $570 \mu \mathrm{g} \mathrm{C} \mathrm{l}^{-1}$ are needed to saturate feeding at $15^{\circ} \mathrm{C}$. Although ingestion at the highest food level was greatest at $15^{\circ} \mathrm{C}$, ingestion at intermediate food levels was lower at $15^{\circ} \mathrm{C}$ than at 8 or $12^{\circ} \mathrm{C}$.
Metridia pacifica ingested 3 to 4 times more carbon per day and had higher filtration rates when fed Corethron hystrix than when fed Thalassiosira weissfloggii (Fig. 3C). Daily ingestion was 15 to $20 \mu \mathrm{g} \mathrm{C}$ ind $^{-1}$ at $500 \mu \mathrm{g} \mathrm{Cl} \mathrm{l}^{-1}$ of $\mathrm{C}$. hystrix, compared to 2.5 to $6 \mu \mathrm{g} \mathrm{C}$ ind $^{-1}$ when fed $T$. weissfloggii. Maximum ingestion $\left(I_{\max }\right)$ was $31.3 \mu \mathrm{g} \mathrm{C}$ ind $\mathrm{d}^{-1} \mathrm{~d}^{-1}$ on the large cell, which is 4 to $6 \times$ and 6 to $15 \times$ greater than when feeding on $T$. weissfloggii in the dark and light, respectively.

\section{Respiration experiments}

Oxygen consumption rates of Metridia pacifica females and $C_{5}$ copepodites are shown in Table 4. Adult female respiration was not clearly related to temperature. The reason for this is not clear; however, water temperature in the deck incubators during the May and August 1984 cruises was slightly (1 to $3 \mathrm{C}^{\circ}$ ) warmer than that of the surface water. Thus, the copepods experienced higher temperatures in the respiration experiments than they would encounter normally in surface waters at that time; the absence of a relationship between metabolic rate and temperature might be explained by the copepods not being acclimatized to higher than ambient temperatures. Respiration by $\mathrm{C}_{5}$ copepodites at 8 to $9^{\circ} \mathrm{C}$ was approximately half that of adult females at the same temperature. Respiration as fraction of body weight was 4 to $10 \% \mathrm{~d}^{-1}$ for both $\mathrm{C}_{5}$ copepodites and adult females.

\section{Seasonal variation in length and length-weight relations}

Seasonal variation in total length was most pronounced for adult females (Fig. 4). Mean length of adult females was greatest $(3.23 \mathrm{~mm})$ on 21 June and $10 \mathrm{July} 1980$, and least $(2.31 \mathrm{~mm})$ on 1 January 1981. Mean length of $\mathrm{C}_{3}$ to $\mathrm{C}_{5}$ copepodites also varied seasonally, although the amplitude of the seasonal pattern was far less than that of adult females (Fig. 4). Length of $\mathrm{N}_{4}$ and $\mathrm{N}_{5}$ did not vary seasonally. 
Table 4. Metridia pacifica. Respiration

\begin{tabular}{|ccccc|}
\hline Stage & Temp. $\left({ }^{\circ} \mathrm{C}\right)$ & $\mathrm{N}$ & $(\mu) \mathrm{O}_{2}$ ind $\left.^{-1} \mathrm{~h}^{-1}\right)$ & Mean $(\mathrm{SD})$ \\
\hline Female & 9.0 & 6 & $0.397(0.070)$ & $0.191(0.034)$ \\
Female & 8.0 & 6 & $0.267(0.140)$ & $0.129(0.067)$ \\
Female & 14.6 & 2 & 0.326 & 0.157 \\
$\mathrm{C}_{5}$ & $8-9$ & 6 & $0.155(0.028)$ & $0.075(0.014)$ \\
- Respiratory quotient of 0.9 assumed & & & \\
\hline
\end{tabular}

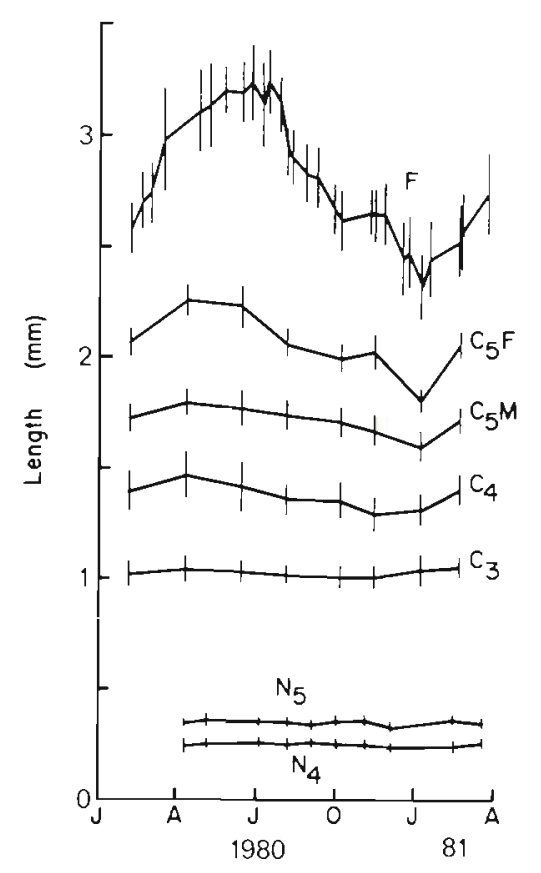

Fig. 4. Metridia pacifica. Seasonal total body length during Feb 1980 to Feb 1981

The length-weight relation for Metridia pacifica is shown in Fig. 5. Triangles represent values determined from formalin-preserved samples, which according to Landry (1978) and Omori (1978) underestimate the true carbon values by approximately $30 \%$. The measured carbon contents of $\mathrm{N}_{4}$ to $\mathrm{C}_{3}$ have been multiplied by 1.43 to correct for this weight loss. The corrected values are indicated by squares. For $\mathrm{C}_{1}$ to adults, the length-weight relation, fit by least-squares regression, was best described by:

$$
W=3.83 L^{2.46} \quad R^{2}=0.94 \quad N=27
$$

where $\mathrm{L}=$ total length in $\mathrm{mm}$; and $\mathrm{W}=$ body weight as $\mu \mathrm{g}$ carbon.

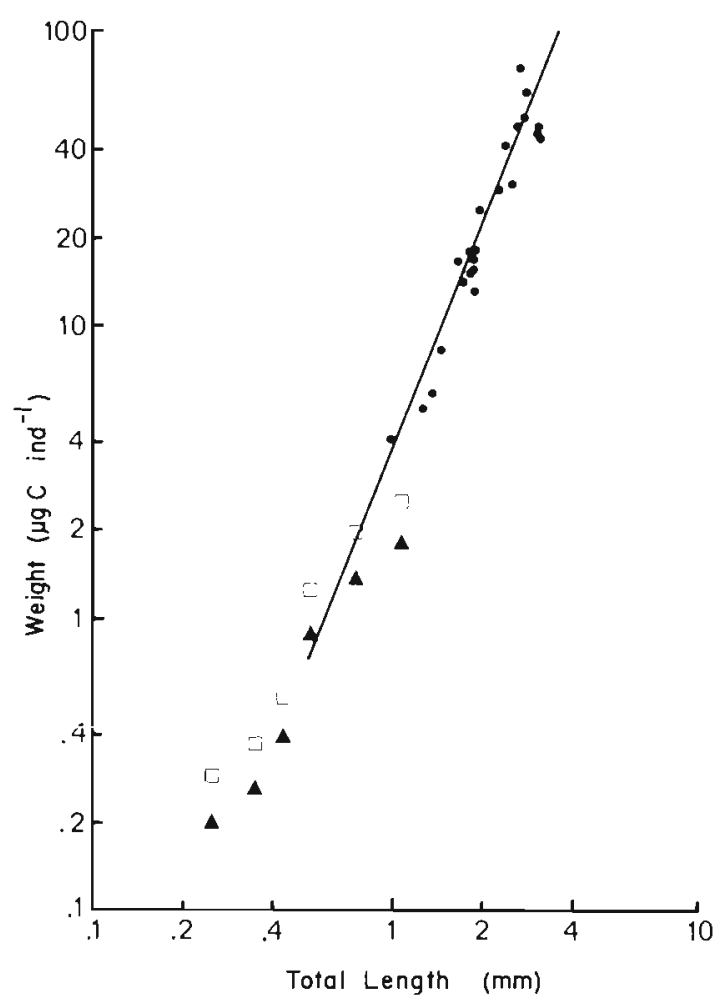

Fig. 5. Metridia pacifica. Length-weight relation. (•) Live sorted; (ム) formalin-preserved; ( $\square$ ) corrected formalin-preserved

\section{DISCUSSION}

\section{Feeding rates}

Metridia pacifica $\mathrm{C}_{5}$ and females exhibited a marked diel feeding periodicity during May 1984 at Station P; ingestion and filtration rates were an order of magnitude greater at night than during the day. Diel variation in gut pigment content of copepods has been reported previously for Centropages hamatus (Nicolajsen et al. 1983, Head et al. 1984), Centropages typicus (Mackas \& Bohrer 1976, Dagg \& Grill 1980), Metridia lucens (Mackas \& Bohrer 1976), Pseudocalanus sp. (Nicolajsen et al. 1983) and Temora longicornis (Head 
et al. 1984). In several of these earlier gut content studies, however, it was not possible to separate the effects of (1) daytime downward migration away from high food concentration from (2) diel variation in individual feeding behavior. Since chlorophyll a values of the upper 70 to $100 \mathrm{~m}$ were nearly homogeneous (Lorenzen 1984) in the present study, the diel cycle of gut pigment content reflects a real day-night difference in feeding intensity, similar to that found by Baars \& Oosterhuis (1984) for species of Temora, Pseudocalanus, Centropages and Calanus and by Head et al. (1985) for the non-migratory Calanus hyperboreus and C. glacialis in the Arctic.

The pigment content of each Metridia pacifica female during the daytime represented the filtration of 1 to $2 \mathrm{ml}$ of the surrounding water, whereas the pigment content at night represented filtration of 6 to $8 \mathrm{ml}$ of water. Mackas \& Burns (1986) report that recently starved $M$. pacifica females had a first hour filtration rate of $1.9 \mathrm{ml} \mathrm{ind} \mathrm{m}^{-1} \mathrm{~h}^{-1}$ in low-food (1 $\left.\mu \mathrm{g} \mathrm{chl} \mathrm{a} \mathrm{l}^{-1}\right)$ conditions. The filtration rate estimates reported here following apparent starvation (during the day) are much greater ( 6 to $13 \mathrm{ml}$ ind $^{-1} \mathrm{~h}^{-1}$ ). Mackas \& Burns (1986) also report a turnover time of $0.6 \mathrm{~h}$ for $M$. pacifica females. This corresponds to a gut evacuation rate of $1.3 \% \mathrm{~min}^{-1}$, similar to my estimate of $1.8 \%$ $\mathrm{min}^{-1}$. Ingestion of chlorophyll by adult females in May 1984 was $51.7 \mathrm{ng}$ chl $a$ ind $^{-1}$ when summed over $24 \mathrm{~h}$. Assuming a carbon to chlorophyll a ratio of 60 for Station $P$ in May 1984 (Welschmeyer pers. comm.), daily ingestion was $3.1 \mu \mathrm{g} \mathrm{C}$ female ${ }^{-1}$. For adult females of $43 \mu \mathrm{g} \mathrm{C}$, this ration is equal to $7.2 \%$ of body carbon per day. A similar calculation for $\mathrm{C}_{5}$ reveals that daily ingestion was $0.59 \mu \mathrm{g} \mathrm{C}$, which amounts to only $2.4 \%$ of body carbon.

Clearance rates determined for Metridia pacifica females in long-term bottle incubation experiments were slightly lower than in situ rates estimated from gut pigment content. Maximum clearance rate on small cells (at low concentration $\left(100 \mu \mathrm{g} \mathrm{C} \mathrm{l}^{-1}\right)$ ) was $30 \mathrm{ml} \mathrm{d}^{-1}$ compared to the integrated in situ clearance rate of $76 \mathrm{ml} \mathrm{d}^{-1}$. At unnaturally high food concentrations clearance rates in the incubations were even lower ( $<20 \mathrm{ml}$ ind $\mathrm{d}^{-1} \mathrm{~d}^{-1}$ ). When food concentrations in bottle incubations were significantly higher than ambient food levels at Station $\mathrm{P}$, daily ration of adult females ranged from $3.9 \%$ of body weight when preconditioned on a high concentration of Thalassiosira weissfloggii, to $62 \%$ when fed the large diatom Corethron hystrix. However, in containers with food concentrations comparable to those observed at Station P, daily consumption was generally less than $1 \%$ of body carbon.

The results of gut fluorescence analyses and laboratory incubation experiments were consistent in that both indicated that Metridia pacifica have relatively low ingestion rates. Ingestion as a fraction of body weight was usually less than $7 \% \mathrm{~d}^{-1}$, except when the copepods were offered unnaturally high food concentrations.

There are relatively few other studies of feeding in Metridia with which the present results may be compared. Haq (1967) measured the feeding rate of $M e$ tridia lucens upon several foods, including both phytoplankton cells and Artemia nauplii. Ingestion rates depended upon the quantity and type of food offered. Maximum ingestion of phytoplankton food was less on small cells than on large cells. The results from the present experiments agree with those results, as maximum ingestion rates were much higher when $M$. pacifica were offered Corethron hystrix, rather than Thalassiosira weissfloggii. Moreover, daily consumption of phytoplankton by $M$. lucens was low; ingestion ranged from $0.44 \mu \mathrm{g} \mathrm{C}$ ind $\mathrm{d}^{-1} \mathrm{~d}^{-1}$ when fed Dunaliella to $2.10 \mu \mathrm{g} \mathrm{C}$ ind ${ }^{-1} \mathrm{~d}^{-1}$ when fed Thalassiosira nordenskioldii (Haq 1967). As mentioned earlier, the gut evacuation rate measured here is quite similar to that reported by Mackas \& Burns (1986), although the individual filtration rate, following a starvation period, is roughly 3 to $5 \times$ greater in the present study than was found by Mackas \& Burns. Daily ration of $M$. pacifica females can be estimated from their data (Table 1 of Mackas \& Burns 1986) by applying their gut turnover time $\left(1.3 \% \mathrm{~min}^{-1}\right)$ to the average pigment in the gut, assuming that the carbon content of Metridia is $43 \%$ of the dry weight, and that the $\mathrm{C}$ : Chl ratio of the phytoplankton (Coscinodiscus) is 30 . These calculations indicate rations of $2.6 \% \mathrm{~d}^{-1}$ and $22 \% \mathrm{~d}^{-1}$ for recently starved copepods feeding at low and high food concentrations, respectively. Non-starved specimens had slightly lower rations of $1.9 \% \mathrm{~d}^{-1}$ and $12.6 \% \mathrm{~d}^{-1}$ in low and high food concentrations. The low food results are similar to the daily rations obtained for $M$. pacifica in the present study.

Other pelagic crustaceans similar in size to Metridia pacifica and $M$. lucens have much greater daily rations. Paffenhöfer (1971) reported daily ration of Calanus helgolandicus (= pacificus) of $60 \mu \mathrm{g}$ carbon body weight to be $55 \% \mathrm{~d}^{-1}$. Mackas \& Burns (1986) observed daily rations of 8 to $12 \% \mathrm{~d}^{-1}$ and 14 to $96 \%$ $\mathrm{d}^{-1}$ for $C$. pacificus feeding on small and large phytoplankters, respectively. Mullin \& Brooks (1970), also working on $C$. pacificus $(45 \mu \mathrm{g} \mathrm{C}$ ), reported the ration as roughly $40 \% \mathrm{~d}^{-1}$. Euphausia pacifica furcilia of 25 to $50 \mu \mathrm{g} \mathrm{C}$ ingested 17 to $30 \% \mathrm{~d}^{-1}$ (Ross 1982). It is not clear why the ingestion rate of Metridia is so much lower than that observed for other pelagic crustaceans of similar size, but it may be related to the size of the food particles. Most of the studies of C. pacificus and $E$. pacifica ingestion were conducted using relatively 
large (19 to $64 \mu \mathrm{m}$ diameter) phytoplankton cells as food. In the present study, $M$. pacifica offered large cells (Corethron hystrix) had ingestion rates as high as $62 \%$ of body carbon per day. Offering large cells as food to $M$. pacifica is not entirely appropriate because, although large phytoplankton cells can at times be abundant in the subarctic Pacific (Clemons \& Miller 1984), the more usual case is for nanophytoplankton to dominate the flora (Booth et al. 1982, Taylor \& Waters 1982). It should be noted also that Mackas \& Burns (1986) also found low daily rations ( 2 to $22 \% \mathrm{~d}^{-1}$ ) with $M$. pacifica feeding on large $(40$ to $50 \mu \mathrm{m})$ cells.

\section{Metabolic rate}

Fig. 6 indicates that the respiration rates of Metridia pacifica measured in the present study are comparable to previously published data for this species and $M$. lucens. Dagg et al. (1982) present a relation between

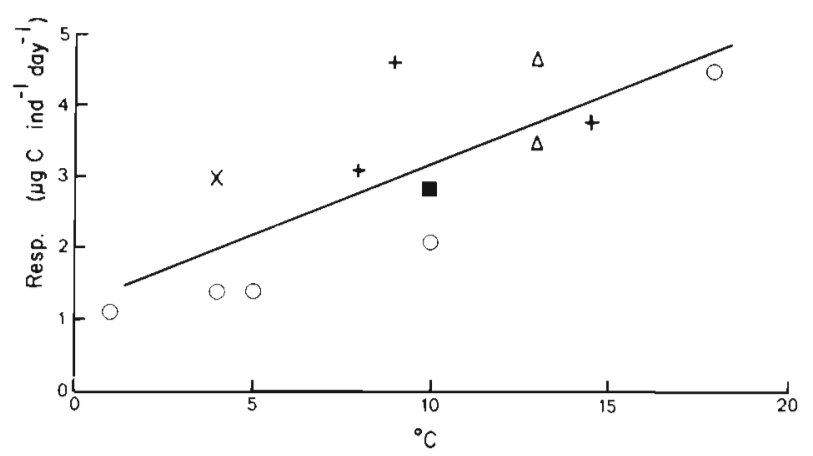

Fig. 6. Metridia pacifica and $M$. lucens. Summary of respiration rates of adult females. Data from (-) Marshall \& Orr (1962); (O) Haq (1967); ( $\Delta$ ) Ikeda (1976); (x) Dagg et al. (1982); $(+)$ present study

metabolism and body size determined for zooplankton, including $M$. pacifica, from the Bering Sea. The slope of their relation $(b=0.884)$ is similar to the slope of boreal $(b=0.834)$ and subtropical $(b=0.867)$ species reported by Vidal \& Whitledge (1982). Vidal \& Whitledge (1982) concluded that the slopes of the allometric equation describing metabolism as a function of body weight did not differ for pelagic crustaceans of boreal and subtropical habitats. In contrast, the intercept of the relation between weight and metabolism increased with increased habitat temperature.

In the present study, respiration of Metridia pacifica was measured at a few temperatures only, and only for adult females and $\mathrm{C}_{5}$ copepodites (Table 4). Respiration rates of younger copepodite stages were assessed indirectly by a relation developed to express respiration as a function of habitat temperature and body size. Adult female respiration increased linearly with tem- perature over the temperature range from 2 to $18^{\circ} \mathrm{C}$ (Fig. 6). M. pacifica females in the Bering Sea were larger $(\sim 100 \mu \mathrm{g} \mathrm{C})$ (Dagg et al. 1982) than those from coastal Oregon or Station P; thus, respiration for females from the Bering Sea was calculated for $45 \mu \mathrm{g}$ individuals using the equations provided by Dagg et al. (1982). Assuming the allometric equation appropriately describes the relation between metabolism and body size, and assuming also that the respiration data shown in Fig. 6 were obtained from adult females of constant body size, an empirical relation was derived to describe the temperature (T) dependence of the respiration constant (a) of the allometric equation. The equation best describing this relation is:

$$
\mathrm{a}=0.037+0.006 \mathrm{~T} \quad \mathrm{R}^{2}=0.60 \quad \mathrm{p}<0.005
$$

Using 0.884 (Dagg et al. 1982) as the slope of the allometric equation then:

$$
\mathrm{R}=(0.037+0.006 \mathrm{~T}) \mathrm{W}_{\mathrm{c}}^{0.884}
$$

where $\mathrm{R}=$ respiration rate in $\mu \mathrm{g} \mathrm{C}$ ind $\mathrm{d}^{-1} \mathrm{~d}^{-1} ; \mathrm{T}=$ temperature in ${ }^{\circ} \mathrm{C}$; and $W_{c}=$ body weight in $\mu$ g carbon. Finally, by substituting Equation (6) into (8) we obtain:

$$
R=(0.037+0.006 T) \cdot\left(3.83 L^{2.46}\right)^{0.884}
$$

which allows a prediction of metabolic rate from habitat temperature and total body length.

An empirical relation such as (8) or (9) must be applied with caution, particularly when it is derived from a small set of data, as is the case here. It is desirable to compare predictions of the equation with experimentally measured values. Since the dependence of the respiration constant (a) on temperature was derived from data on adult females only, a test is to compare the predicted respiration of $\mathrm{C}_{5}$ copepodites (approximately $25 \mu \mathrm{g} \mathrm{C}$ ) at $8.5^{\circ} \mathrm{C}$ to that reported in Table 4 . The respiration rate of $1.54 \mu \mathrm{g}$ carbon ind $^{-1}$ $\mathrm{d}^{-1}$ predicted by the equation falls within the $95 \%$ confidence interval of the experimentally determined rate for $\mathrm{C}_{5}$ copepodites $(\mathrm{X}=1.80 ; \mathrm{S}=0.33 ; \mathrm{N}=6)$.

\section{Carbon budget of $\mathrm{C}_{5}$ copepodites and adult females}

From the data on respiration and in situ feeding rates in May 1984, a carbon budget was constructed to evaluate the ability of Metridia pacifica to survive at rations available in the field. Daily carbon ingestion of adult females and $\mathrm{C}_{5}$ copepodites at Station $\mathrm{P}$ during May was estimated from the in situ gut content results, and compared to calculated metabolic demands. Assuming that feeding occurs at night at the surface $\left(6.0^{\circ} \mathrm{C}\right)$ and that days are spent at $250 \mathrm{~m}\left(3.8^{\circ} \mathrm{C}\right)$, metabolic demands are calculated to be 1.90 and 
$1.13 \mu \mathrm{g} \mathrm{C}$ copepod ${ }^{-1} \mathrm{~d}^{-1}$ for females and $\mathrm{C}_{5}$, respectively. If assimilation efficiency is $70 \%$, ingestion of 2.71 and $1.61 \mu \mathrm{g} \mathrm{C}$ copepod $\mathrm{d}^{-1} \mathrm{~d}^{-1}$ is required for metabolism. Given the carbon to chlorophyll ratio of 60 , the daily ingestion per female and $\mathrm{C}_{5}$, estimated from in situ gut pigment determinations and a gut evacuation rate of $1.8 \% \mathrm{~min}^{-1}$, are 3.10 and $0.59 \mu \mathrm{g} \mathrm{C}$ copepod $^{-1}$, respectively. Thus, adult females ingested sufficient food to support their metabolism and have a little left for growth or reproduction, while $\mathrm{C}_{5}$ obtained food for only $37 \%$ of their daily metabolic needs with no provision for growth.

Several assumptions were made to enable these comparisons, and errors in them, alone or in concert, may cause the poor agreement between metabolic requirements and daily ingestion of the fifth copepodites. The possibilities include the following: the carbon to chlorophyll ratio is in error; respiration rate is overestimated; gut evacuation rate is underestimated; ingestion rate is too low because of pigment destruction; the copepods supplement their diet by feeding on animals or seston; assimilation efficiency is greater than $70 \%$; or during this particular day Metridia pacifica $\mathrm{C}_{5}$ did not get enough to eat. The last possibility is difficult to test, can only work on the short term, and is not discussed further. The other hypotheses are testable and can be evaluated for $\mathrm{C}_{5}$. The carbon to chlorophyll value may be in error, but other realistic values for this parameter (20 to 100) fail also to balance the energy budget. Assimilation efficiency, even if assumed to be $100 \%$, an unlikely value, could not by itself balance the energy budget.

Respiration estimates from several sources (Fig. 6) were used to derive the respiration equation. The container size, acclimation and incubation times, and methods used to measure respiration varied widely, yet the results agree reasonably well. This reduces, but does not eliminate, the possibility of error; the respiration rates from all sources may be elevated above those found in situ. Considering the possibility that Metridia supplement their diet with animal prey, the guts of a few $C_{5}$ and several dozen females were examined microscopically for evidence of animal remains, and none, except a very few nasselarian radiolaria, were found (Batchelder pers. obs.), although both Mullin (1966) and Haq (1967) found that Metridia readily ingest and grow on Artemia nauplii. However, consumption of colorless flagellates by Metridia would likely go undetected in these microscopic examinations. Thus, the role of heterotrophic flagellates in the diet of $M$. pacifica remains unknown.

As was stated earlier, the extent of pigment degradation within the gut of Metridia was not evaluated. The present budget calculations assume that pigment destruction was on the order of $34 \%$, similar to that found in Calanus pacificus by Shuman \& Lorenzen (1975). If greater than $34 \%$ pigment destruction occurred then the total daily ingestion rate, as estimated from in situ gut fluorescence, would be underestimated. Attempting to balance the carbon budget of $\mathrm{C}_{5}$ by adjusting the pigment destruction rate alone requires that $75 \%$ of the pigment ingested by the copepod be degraded within the gut prior to measurement of the gut fluorescence. Degradation rates greater than $90 \%$ have been reported for C. glacialis and C. hyperboreus (Conover et al. 1986).

The carbon budget balance turns out to be sensitive to the choice of gut evacuation rate. The gut evacuation rate of $1.8 \% \mathrm{~min}^{-1}$ that was used in this analysis was determined using adult females only. It may not be appropriate to apply that rate to younger life stages. Furthermore, in the evacuation rate experiments described above the copepods were transferred to filtered seawater to follow the time course of pigment loss from the gut, arid perhaps individuals so treated retain the food already in the gut longer than when other food is available (Murtaugh 1984). If so, evacuation rates would be underestimated. All other parameters being unchanged, the carbon budget of $C_{5}$ can be balanced so that assimilated carbon equals respired carbon if evacuation rate is increased from $1.8 \%$ $\min ^{-1}$ to $5.0 \% \mathrm{~min}^{-1}$. Although this gut evacuation rate is twice the highest rate $\left(2.4 \% \mathrm{~min}^{-1}\right)$ measured for adult females, gut evacuation rates as high as $4 \%$ $\mathrm{min}^{-1}$ have been reported for Neocalanus plumchrus (Dagg \& Wyman 1983) and Temora, Pseudocalanus, Centropages, and Calanus spp. (Baars \& Oosterhuis 1984).

\section{Potential contribution of Metridia pacifica herbivory in controlling phytoplankton stocks}

The agreement between the measured and predicted respiration of $\mathrm{C}_{5}$ copepodites encouraged me to use Equation (9) to estimate the metabolism of the $C_{3}$ to $C_{5}$ copepodite and adult female populations of Metridia pacifica at Station $P$ from seasonal abundance estimates (Batchelder 1985) and size distribution. All of these life stages migrate vertically, spending the night near the surface and the day at depth. During this migration, the copepod passes through a marked temperature gradient, the intensity of which varies with season. A simple model was developed using temperature of the surface mixed layer and temperature at $250 \mathrm{~m}$, for night and day periods, respectively. Migration from the surface to $250 \mathrm{~m}$ and back were considered to occur instantaneously at sunrise and sunset (U. S. Naval Observatory 1979), respectively.

Respiration by the $\mathrm{C}_{3}$ to adult populations of $\mathrm{Me}$ - 
Table 5. Metridia pacifica. Daily population respiration $\left(\mathrm{mg} \mathrm{C} \mathrm{m}^{-2}\right)$ of $\mathrm{C}_{3}$ to adult female, total daily consumption, and estimated daily primary production ( $\mathrm{mg} \mathrm{C} \mathrm{m}^{-2}$ ) from Stephens (1968)

\begin{tabular}{|c|c|c|c|c|c|c|c|c|c|c|c|}
\hline Date & $\mathrm{C}_{3}$ & $\mathrm{C}_{4}$ & $\mathrm{C}_{5} \mathrm{M}$ & $\mathrm{C}_{5} \mathrm{~F}$ & Fem. & Sum & $\begin{array}{c}\text { (A) } \\
\text { Cons. }\end{array}$ & $\begin{array}{c}\text { (B) } \\
\text { Cons. }\end{array}$ & $\begin{array}{l}\text { (C) } \\
\text { Primary } \\
\text { prod. }\end{array}$ & $\begin{array}{r}\text { Fract } \\
\text { production } \\
(\mathrm{A} / \mathrm{C}) \times 100\end{array}$ & $\begin{array}{l}\text { ion of } \\
\text { consumed } \\
(B / C) \times 100\end{array}$ \\
\hline 6 Feb 80 & 0.50 & 0.79 & 1.40 & 1.58 & 2.48 & 6.75 & 9.6 & 13.8 & 27.2 & 35.3 & 50.7 \\
\hline 10 Apr 80 & 0.40 & 0.59 & 0.71 & 0.43 & 1.49 & 3.62 & 5.2 & 7.4 & 94.3 & 5.5 & 7.8 \\
\hline 11 Jun 80 & 0.08 & 0.30 & 0.39 & 1.16 & 5.23 & 7.16 & 10.2 & 14.6 & 163.2 & 6.3 & 8.9 \\
\hline 1 Aug 80 & 0.11 & 0.98 & 0.93 & 0.61 & 2.85 & 5.48 & 7.8 & 11.2 & 136.6 & 5.7 & 8.2 \\
\hline 1 Oct 80 & 1.12 & 1.45 & 1.29 & 1.37 & 4.59 & 9.82 & 14.0 & 20.0 & 58.1 & 24.1 & 34.4 \\
\hline 9 Nov 80 & 0.86 & 1.30 & 0.33 & 0.64 & 2.91 & 6.04 & 8.6 & 12.3 & 23.0 & 37.4 & 53.5 \\
\hline $1 \mathrm{Jan} 81$ & 2.39 & 2.70 & 1.84 & 1.20 & 1.95 & 10.08 & 14.4 & 20.6 & 8.2 & 175.6 & 251.2 \\
\hline 15 Feb 81 & 0.08 & 0.88 & 0.89 & 2.25 & 2.09 & 6.19 & 8.8 & 12.6 & 35.4 & 24.9 & 35.6 \\
\hline
\end{tabular}

tridia pacifica was calculated for 8 dates from 6 February 1980 to 15 February 1981 (Table 5). Predicted respiration varied from $0.08 \mathrm{mg} \mathrm{C} \mathrm{m}^{-2} \mathrm{~d}^{-1}$ for $\mathrm{C}_{3}$ in June 1980 and February 1981, to $5.2 \mathrm{mg} \mathrm{C} \mathrm{m}^{-2} \mathrm{~d}^{-1}$ for the adult female population in June 1980. Adult female respiration generally accounted for 30 to $50 \%$ of the sum of the respiration of all stages. Exceptions were June 1980, when copepodite density was low and $73 \%$ of the total respiration was by females, and January 1981, when copepodite stages were numerous and adult female respiration was only $19 \%$ of total respiration. Total daily consumption by $\mathrm{C}_{3}$ to adult $M$. pacifica was estimated assuming no growth or reproduction and an assimilation efficiency of $70 \%$ and compared to seasonal average daily primary production (Stephens 1968) (Table 5). Assuming herbivorous feeding only, the percentage of total daily primary production ingested by the older copepodite stages of $M$. pacifica ranged from $5 \%$ during the spring peak of primary production to $175 \%$ during midwinter.

It is important to remember that the consumption estimates discussed to this point provide for neither growth nor reproduction. Yet, development progressed, and growth occurred throughout the year except possibly during late December 1980 to early February 1981 (Batchelder 1985). By making the additional assumption that $70 \%$ of the food assimilated is respired (Sushchenya 1970), with the remaining $30 \%$ channeled to growth and reproduction, an estimate of consumption which provides for growth and reproduction as well as metabolism was obtained (Table 5). Only 8 to $9 \%$ of daily primary production is necessary to satisfy the growth, reproductive and metabolic needs of $\mathrm{C}_{3}$ to adults during summer. On 1 January 1981, however, consumption to meet metabolic demands alone was 1.7 times production. Batchelder
(1986) found that adult female Metridia pacifica failed to produce eggs during late December to early February. The results of the model presented here suggest that there was insufficient food at that time to satisfy the metabolic requirements of the copepods, much less provide for growth or reproduction.

The respiration rate of the adult female population was calculated for all dates for which the length distribution was known, and compared to daily primary production (Fig. 7). The results confirm the conclusions derived from the fewer data on the younger stages; less than $5 \%$ of spring and summer daily primary production and roughly 20 to $40 \%$ of autumn and winter production was consumed by adult females. The increased fraction of production which was consumed
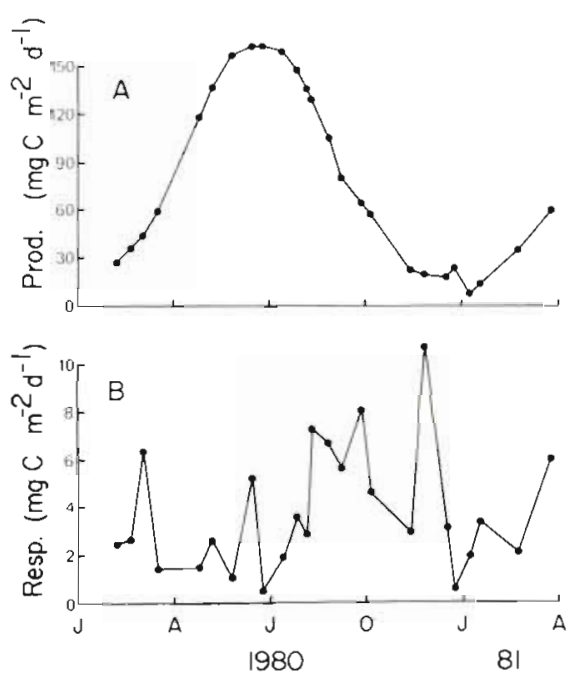

Fig. 7. (A) Seasonal cycle of primary production at Station P. (Approximate mean compiled from Stephens 1968); (B) Metridia pacifica. Seasonal cycle of water column respiration by the population of adult females 
by females in autumn and winter was due in part to lower primary production, and in part, to the increased number of females. The large fluctuations, as low as $3 \%$ and as high as $80 \%$, in the percent of primary production consumed by Metridia pacifica females during autumn and early winter are caused by the highly variable copepod population density estimates. These calculations suggest that the $M$. pacifica population has the grazing potential to maintain phytoplankton stocks at a low level during autumn and early winter but has relatively little impact on plant populations during the spring and summer peak of primary production.

Acknowledgements. I am grateful for the shipboard assistance I received from the investigators and participants in SUPER. C. Miller, T. Cowles, R. Conover and 2 anonymous reviewers provided helpful comments on drafts of this paper. Sandy Moore provided the CHN analysis. The research was supported by National Science Foundation contracts OCE7981687, OCE-8201899, and OCE-8309078 to C. Miller.

\section{LITERATURE CITED}

Baars, M. A., Oosterhuis, S. S. (1984). Diurnal feeding rhythms in North Sea copepods measured by gut fluorescence, digestive enzyme activity and grazing on labelled food. Neth. J. Sea Res. 18: 97-119

Batchelder, H. P. (1985). Seasonal abundance, vertical distribution and life history of Metridia pacifica (Copepoda: Calanoida) in the oceanic subarctic Pacific. Deep Sea Res. 32: 949-964

Batchelder, H. P. (1986). A staining technique for determining copepod gonad maturation: application to Metridia pacifica from the northeast Pacific Ocean. J. Crust. Biol. 6: $227-231$

Booth, B. C., Lewin, J., Norris, R. E. (1982). Nanoplankton species predominant in the subarctic Pacific in May and June 1978. Deep Sea Res. 29: 185-200

Clemons, M. J., Miller, C. B. (1984). Blooms of large diatoms in the oceanic, subarctic Pacific. Deep Sea Res. 31: 85-95

Conover, R. J., Durvasula, R., Roy, S., Wang, R. (1986). Probable loss of chlorophyll-derived pigments during passage through the gut of zooplankton, and some of the consequences. Limnol. Oceanogr. 31: 878-887

Dagg, M. J., Grill, D. W. (1980). Natural feeding rates of Centropages typicus females in the New York bight. Limnol. Oceanogr. 25: 597-609

Dagg, M. J., Vidal, J., Whitledge, T E., Smith, S., Howe, S., Judkins, D. (1982). The feeding, respiration and excretion of zooplankton in the Bering Sea during a spring bloom. Deep Sea Res. 29: 45-63

Dagg, M. J., Wyman, K. D. (1983). Natural ingestion rates of the copepods Neocalanus plumchrus and $N$ cristatus calculated from gut contents. Mar. Ecol. Prog. Ser 13: 37-46

Elliot, J. M., Persson, L. (1978). The estimation of daily rates of food consumption for fish. J. Anim. Ecol. 47: 977-991

Frost, B. W. (1972). Effects of size and concentration of food particles on the feeding behavior of the marine planktonic copepod Calanus pacificus. Limnol. Oceanogr. 17: $805-815$
Haq, S. M. (1967). Nutritional physiology of Metridia lucens and $M$. longa from the Gulf of Maine. Limnol. Oceanogr. 12: $40-51$

Head, E. J. H., Harris, L. R., Abou Debs, C. (1985). Effect of daylength and food concentration on in situ diurnal feeding rhythms in Arctic copepods. Mar. Ecol. Prog. Ser. 24: $281-288$

Head, E. J. H., Wang, R., Conover, R. J. (1984). Comparison of diurnal feeding rhythms in Temora longicornis and Centropages hamatus with digestive enzyme activity. J. Plankton Res. 6: 543-551

Heinrich, A. K. (1957). The breeding and development of the dominant copepods in the Bering Sea. Trudy vses. gibrobiol. Obshch. 8: 143-162

Heinrich, A. K. (1962). The life history of plankton animals and seasonal cycles of plankton communities in the oceans. J. Cons, perm. int. Explor. Mer 27: 15-24

Ikeda, T. (1976). The effect of laboratory conditions on the extrapolation of experimental measurements to the ecology of marine zooplankton. I. Effect of feeding condition on the respiration rate. Bull. Plank. Soc. Japan 23: 1-10

Ivlev, V. S. (1955). Experimental ecology of the feeding of fishes. Yale University Press, New Haven

Landry, M. R. (1978). Population dynamics and production of a planktonic marine copepod, Acartia clausii, in a small temperate lagoon on San Jaun Island, Washington. Int. Revue ges. Hydrobiol. 63: 77-119

Lorenzen, C. J. (1984). Chlorophyll-phaeopigment profiles from SUPER 1 cruise (28 April-24 May 1984) and SUPER 2 cruise (30 July-26 August 1984). Oregon State University, Corvallis, Reference 84-14

Mackas, D., Bohrer, R. (1976). Fluorescence analysis of zooplankton gut contents and an investigation of diel feeding patterns. J. exp. mar. Biol. Ecol. 25: 77-85

Mackas, D. L., Burns, K. E. (1986). Poststarvation feeding and swimming activity in Calanus pacificus and Metridia pacifica. Limnol. Oceanogr. 31: 383-392

Marshall, S. M., Orr, A. P. (1962). Food and feeding in copepods. Rapp. P-v. Réun. Cons. perm. int. Explor. Mer 153: $92-98$

Miller, C. B., Frost, B. W., Batchelder, H. P., Clemons, M. J., Conway, R. E. (1984). Life histories of large, grazing copepods in a subarctic ocean gyre: Neocalanus plumchrus, Neocalanus cristatus, and Eucalanus bungii in the northeast Pacific. Progr. Oceanogr. 13: 201-243

Mullin, M. M. (1966). Selective feeding by calanoid copepods from the Indian Ocean. In: Barnes, H. (ed.) Some contemporary studies in marine science. George Allen and Unwin Ltd., London, p. 545-554

Mullin, M. M., Brooks, E. R. (1970). Growth and metabolism of two planktonic, marine copepods as influenced by temperature and type of food. In: Steele, J. H. (ed.) Marine food chains. University of California Press, Berkeley, p. 74-95

Mullin, M. M., Sloan, P. R., Eppley, R. W. (1966). Relationships between carbon content, cell volume, and area in phytoplankton. Limnol. Oceanogr. 11: 307-311

Murtaugh, P. A. (1984). Variable gut residence time: problems in inferring feeding rate from stomach fullness of a mysid crustacean. Can. J. Fish. Aquat. Sci. 41: 1287-1293

Nicolajsen, H., Mohlenburg, F., Kiørboe, T (1983). Algal grazing by the planktonic copepods Centropages hamatus and Pseudocalanus sp.: diurnal and seasonal variation during the spring phytoplankton bloom in the $\varnothing$ resund. Ophelia 22: 15-31

Omori, M. (1978). Some factors affecting on dry weight, organic weight and concentrations of carbon and nitrogen 
in freshly prepared and in preserved zooplankton. Int Revue ges. Hydrobiol. 63: 261-269

Paffenhöfer, G.-A. (1971). Grazing and ingestion rates of nauplii, copepodids and adults of the marine planktonic copepod Calanus helgolandicus. Mar. Biol. 11. 286-298

Parslow, J. S. (1981). Phytoplankton-zooplankton interactions: data analysis and modelling (with particular reference to Ocean Station $\mathrm{P}\left(50^{\circ} \mathrm{N}, 145^{\circ} \mathrm{W}\right)$ and controlled ecosystem experiments). Ph. D. thesis, Univ. of British Columbia, Vancouver

Parsons, T. R., LeBrasseur, R. J., Fulton, J. D. (1967). Some observations on the dependence of zooplankton grazing on the cell size and concentration of phytoplankton blooms. J. oceanogr. Soc. Japan 23: 10-17

Parsons, T. R., Takahashi, M., Hargrave, B. (1984). Biological oceanographic processes. 3rd edn. Pergamon Press, Oxford

Ross, R. M. (1982). Energetics of Euphausia pacifica. II. Complete carbon and nitrogen budgets at $8^{\circ} \mathrm{C}$ and $12^{\circ} \mathrm{C}$ throughout the life span. Mar. Biol. 68: 15-23

Runge, J. A. (1980). Effects of hunger and season on the feeding behavior of Calanus pacificus. Limnol. Oceanogr 25: $134-145$
Shuman, F. R., Lorenzen, C. J. (1975). Quantitative degradation of phaeopigments by a marine herbivore. Limnol Oceanogr. 20: 580-586

Stephens, K. (1968). Data record, productivity measurements in the northeast Pacific with associated chemical and physical data, January 1964 to December 1965. Fish. Res. Bd. Can., Manuscript Report Series (Oceanography and Limnology), No. 257

Sushchenya, L. M. (1970). Food rations, metabolism and growth of crustaceans. In: Steele, J. H. (ed.) Marine food chains. University of California Press, Berkeley, p. $127-141$

Taylor, F. J. R., Waters, R. E. (1982). Spring phytoplankton in the subarctic North Pacific Ocean. Mar. Biol. 67: 323-335

U. S. Naval Observatory (1979). The American Ephemeris and Nautical Almanac for the Year 1980. U. S. Government Printing Office, Washington, D.C

Vidal, J., Whitledge, T. E. (1982). Rates of metabolism of planktonic crustaceans as related to body weight and temperature of habitat. J. Plankton Res. 4, 77-84

This article was presented by Dr. R. J. Conover; it was accepted for printing on October 22, 1986 